\title{
CORRIGENDUM
}

\section{Inhibiting estrogen responses in breast cancer cells using a fusion protein encoding estrogen receptor- $\alpha$ and the transcriptional repressor PLZF}

L Buluwela ${ }^{1}$, J Pike ${ }^{1}$, D Mazhar ${ }^{1}$, T Kamalati ${ }^{1}$, SM Hart $^{1}$, R Al-Jehani ${ }^{1}$, H Yahaya $^{1}$, N Patel $^{2}$, N Sarwarl $^{1}$, DA Heathcote ${ }^{1}$, O Schwickerath ${ }^{1}$, F Phoenix ${ }^{1}$, R Hill ${ }^{1}$, E Aboagye ${ }^{1}$, S Shousha ${ }^{3}$, J Waxman ${ }^{1}$, NR Lemoine ${ }^{1}$, A Zelent ${ }^{4}$, RC Coombes ${ }^{1}$ and $S$ Ali $^{1}$

Gene Therapy (2005) 12, 862. doi:10.1038/sj.gt.3302529

Correction to: Gene Therapy (2005) 12, 452-460. doi:10.1038/sj.gt.3302421

The above affiliations for the below authors were published incorrectly, the correct affiliations are given below:

N Patel ${ }^{3}$, S Shousha ${ }^{2}$

${ }^{2}$ Department of Histopathology, Imperial College London, London, UK

${ }^{3}$ CR UK Children's Cancer Group, Medical Oncology Unit, Queen Mary, University of London, Charterhouse Square, London, UK

The authors would like to apologise for this error. 